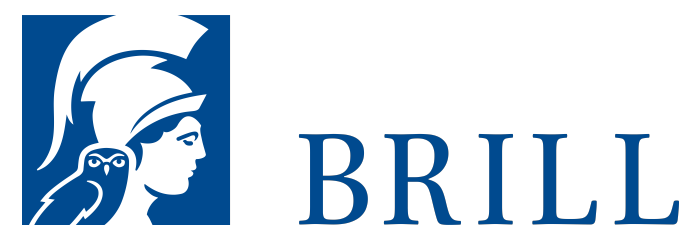

\title{
Paulus - Das Trauma von Stalingrad
}

Eine Biographie

Authors: Torsten Diedrich, Torsten Diedrich, and Torsten Diedrich

Friedrich Paulus (1890-1957) zählt zu den bekann-testen, aber auch umstrittensten Heerführern des Zwei-ten Weltkriegs. Sein Name ist untrennbar mit der Schlacht um Stalingrad und mit dem Untergang seiner 6. Armee verbunden. Das Drama von Stalingrad markierte den Wendepunkt des Krieges - auch für Paulus. Als er am 31. Januar 1943 in den Ruinen der Stadt kapitulierte und für 10 Jahre in russische Gefangenschaft ging, endete eine glänzende Karriere. Er wandelte sich zum Geg-ner Hitlers; 1953 ging er in die DDR, in deren Dienst er sich nehmen ließ - ein Abschnitt seines Lebens, der völlig unbekannt geblieben ist. Torsten Diedrichs fesselnde Biographie ist die erste vollständige Darstellung von Paulus' Lebensweg - vor Stalingrad und danach. Sie räumt mit vielen Vorurtei-len auf und gibt Einblick in das Denken und Handeln eines Mannes, der deutsche Geschichte mitschrieb und dabei zu einer tragischen Figur wurde.

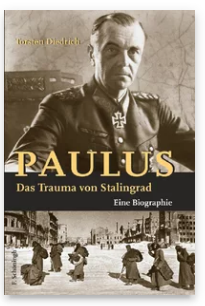

Pages: 580

Seiten, $5^{1 \mathrm{~s} / \mathrm{w}}$

Abb.

Language:

German

Subjects:

Modern History, History

Publisher: Brill |

Schöningh

E-Book (PDF)

Released online:

22 Jun 2020

ISBN: $978-3^{-}$

657-76403-7

List price

USD $\$ 68.00$

Hardback

Publication date:

o1 Apr 2009

ISBN: 978-3-

506-76403-4

List price

USD $\$ 68.00$ 
For more information see brill.com

Order information: Order online at brill.com +44330 333 0049 | customerservices@brill.com Submission information: brill.com/authors

Titles published by Brill | Fink, Brill | mentis or Brill | Schöningh: +49(o)715413279216| brill@brocom.de 